\title{
Cadmium overkill: autophagy, apoptosis and necrosis signalling in endothelial cells exposed to cadmium
}

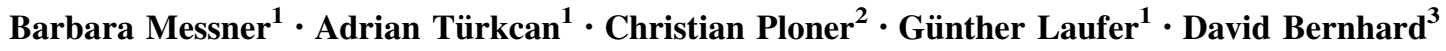

Received: 20 August 2015/Revised: 23 October 2015/Accepted: 9 November 2015/Published online: 20 November 2015

(C) The Author(s) 2015. This article is published with open access at Springerlink.com

\begin{abstract}
Apoptosis, necrosis, or autophagy-it is the mode of cell demise that defines the response of surrounding cells and organs. In case of one of the most toxic substances known to date, cadmium $(\mathrm{Cd})$, and despite a large number of studies, the mode of cell death induced is still unclear. As there exists conflicting data as to which cell death mode is induced by Cd both across various cell types and within a single one, we chose to analyse Cd-induced cell death in primary human endothelial cells by investigating all possibilities that a cell faces in undergoing cell death. Our results indicate that $\mathrm{Cd}$-induced death signalling starts with the causation of DNA damage and a cytosolic calcium flux. These two events lead to an apoptosis signalling-related mitochondrial membrane depolarisation and a classical DNA damage response. Simultaneously, autophagy signalling such as ER stress and phagosome formation
\end{abstract}

Electronic supplementary material The online version of this article (doi:10.1007/s00018-015-2094-9) contains supplementary material, which is available to authorized users.

Barbara Messner

barbara.messner@meduniwien.ac.at

1 Cardiac Surgery Research Laboratory, Department of Surgery, Medical University of Vienna, AKH, Level 8 G9.03, Währinger Gürtel 18-20, 1090 Vienna, Austria

2 Plastic, Reconstructive and Aesthetic Surgery Innsbruck, Department of Operative Medicine, Innsbruck Medical University, Innsbruck, Austria

3 Cardiac Surgery Research Laboratory Innsbruck, University Clinic for Cardiac Surgery, Innsbruck Medical University, Innsbruck, Austria is initiated. Importantly, we also observed lysosomal membrane permeabilization. It is the integration of all signals that results in DNA degradation and a disruption of the plasma membrane. Our data thus suggest that $\mathrm{Cd}$ causes the activation of multiple death signals in parallel. The genotype (for example, $\mathrm{p} 53$ positive or negative) as well as other factors may determine the initiation and rate of individual death signals. Differences in the signal mix and speed may explain the differing results recorded as to the Cd-induced mode of cell death thus far. In human endothelial cells it is the sum of most if not all of these signals that determine the mode of Cd-induced cell death: programmed necrosis.

Keywords Apoptosis - Necrosis - Autophagy · p53 $\cdot$ Lysosome $\cdot$ Calcium

\begin{tabular}{ll}
\multicolumn{2}{l}{ Abbreviations } \\
Cd & Cadmium \\
HUVEC & Human umbilical vein cells \\
ICAM-1 & Intracellular adhesion molecule-1 \\
VCAM-1 & Vascular cell adhesion molecule-1 \\
NO & Nitric oxide \\
ROR & Reactive oxygen radicals \\
$\mathrm{Ca}^{2+}$ & Calcium \\
PI & Propidium iodide \\
EGTA & Ethylene glycol tetra-acetic acid \\
EDTA & Ethylenediaminetetraacetic acid \\
ER & Endoplasmatic reticulum \\
2APB & 2-Aminoethoxydiphenyl borate \\
KD & Knock down \\
OE & Over-expression \\
3MA & 3-Methyladenine \\
LDH & Lactate dehydrogenase \\
LMP & Lysosomal membrane permeabilization
\end{tabular}




\section{Introduction}

Cadmium (Cd) is a toxic heavy metal and pollutant which is ubiquitously distributed in our environment. Human uptake occurs mainly by diet and exposure to cigarette smoke $[1,2]$. The primary target organs in the human body are the kidneys, liver, testes, bones [1-5] and those of the cardiovascular system [6]. Furthermore, $\mathrm{Cd}$ is also known to be carcinogenic within different organs and tissues, which has led the International Agency for Research on Cancer to classify $\mathrm{Cd}$ as a Group I human carcinogen [7, 8].

Based on the variety of target organs of Cd-induced toxicity, a mass of in vitro data exists investigating the effect of $\mathrm{Cd}$ on different cell types. Further, Cd triggers different pathways within different cell types, rendering the landscape even more complex. In this respect one of the most useful examples is in Cd-induced cell death. In general and based upon knowledge gained thus far cell death may be classified into apoptosis, necrosis and autophagy, whereby, above all, detailed molecular and biochemical analyses are indicative of an alternative classification. In this regard, the morphological system of classification is being replaced by a functional system based on the demonstration of detailed signalling pathways and involved molecules [9]. Further adding to the complexity of signalling pathways in response to $\mathrm{Cd}$ toxicity, outcome is also dependent on $\mathrm{Cd}$ concentration; this may serve to explain some of the contradictory reports presently existing as to Cd-induced cell death. Interestingly, a review of literature revealed that even within one cell type different pathway outcomes are described. Important examples of contradictory findings regarding the $\mathrm{Cd}$-induced cell death signals and final outcome are found in experiments performed upon kidney cells. Different in vitro studies have revealed highly diverse signalling pathways, ranging from caspase-independent [10] to caspase-dependent [11-14] apoptosis, although nearly all apoptotic cell death signals have in common an attendant impairment of the mitochondria. Additionally, several studies performed upon kidney cells have demonstrated autophagic signals [15], as well as signals for apoptosis and necrosis [16-18] or apoptosis and autophagy $[19,20]$ within the same cell type. Similarly, Lemaire et al. has reported caspase independent Cd-induced cell death in liver cells [21], whereas within the same cells, Oh et al. and Lasfer et al. provided evidence of caspase-dependent apoptotic signals [22, 23].

In addition to accumulating in known tissues such as the kidney, liver and bone, increased $\mathrm{Cd}$ concentrations were detected in blood serum and aortic walls (up to $20 \mu \mathrm{M}$ ) [6] of young smokers [24]. Beyond that, we and others have demonstrated that $\mathrm{Cd}$ is a risk factor for the development of atherosclerosis leading to fatal cardiovascular outcomes [24-29]. Thus, in addition to activating the cell death machinery [30-32] Cd exerts further effects on endothelial cells. These effects include increased expression of the adhesion molecules ICAM-1 [33, 34] and VCAM-1 [35] which possibly facilitates the adhesion and trans-endothelial migration of leucocytes leading to vascular inflammation. Furthermore, $\mathrm{Cd}$ treatment is known to attenuate the production of the essential vascular signalling molecule nitric oxide (NO) [36-38] thereby reducing the responsiveness of the vascular wall to essential signals. In 2000, Liu et al. demonstrated the genotoxic effect of $\mathrm{Cd}$ in endothelial cells as a result of the production of reactive oxygen radicals (ROR). [39] Cd-caused endothelial dysfunction is triggered by defective migratory ability of endothelial cells and inhibited angiogenesis. [40, 41] Ultimately, exposure of endothelial cells to $\mathrm{Cd}$ once again initiates cell death signals with inconsistent findings regarding the final fatal outcome. Kim et al. and Jung et al. have postulated a caspase-dependent apoptotic signalling pathway [30,31] whereas Wolf et al. detected evidence of cell membrane damage and therefore necrosis [32]. Recently, a study conducted by Dong et al. revealed a novel pathway, whereby $\mathrm{Cd}$-induced apoptotic signals are inhibited and rather autophagy is induced [42]. The process of Cd-induced endothelial cell death becomes further complicated still, as we have now shown that Cd triggers a programmed form of necrotic cell death accomplished by the rupture of lysosomes [43].

Taken together, the results concerning Cd-induced cell death signalling in endothelial cells are inconsistent. Proceeding from the results of a previous study by our group [43] in which we analysed the effect of $\mathrm{Cd}$ as a new risk factor for atherosclerosis development on endothelial cells, the present study aims to provide a highly detailed description of cell death signals within Cd-exposed endothelial cells, from Cd uptake over initiated signalling pathways and involved organelles right up to cell execution.

\section{Materials and methods}

\section{Cell culture}

A detailed description of the isolation of endothelial cells (HUVECs) of umbilical cords is described elsewhere [44]. The isolation and analyses of the used cells is approved by the Ethics Committee of the Medical University of Vienna (EK Nr. 1183/2012). Endothelial cells were cultured on gelatine-coated (Sigma Aldrich, Austria) polysterene culture flasks (TPP, Switzerland) in a specialised endothelial cell 
culture medium (EGM-2, Lonza). Prior to each experiment, the medium was replaced by fresh medium containing the indicated $\mathrm{Cd}$ concentrations. The following inhibitors were used: $50 \mu \mathrm{M}$ calpain-inhibitor III (MDL 28170, Sigma Aldrich, Germany), 2 mM 3-Methyladenine (3MA; M9281, Sigma Aldrich, Germany) and $50 \mu \mathrm{M}$ 2-Aminoethyl diphenylborinate (2APB, D9754, Sigma Aldrich, Germany), $100 \mu \mathrm{M}$ Dantrolene (550-072-M050, Eubio) and $10 \mu \mathrm{M}$ BAPTA (BML-CA411-0025, Enzo Lifesciences).

\section{Comet assay}

To detect DNA damage in endothelial cells after Cd treatment, a Comet-assay was performed according to the manufacturer's instructions (Trevigen, Cat.No.: \#4250-050-K).

\section{Generation of stable BCL-XL OE cells as well as p53 KD HUVECs}

Generation of stable BCL-XL OE cells and knock-down of p53 in endothelial cells was performed as previously described [43]. Monitoring of stable p53 KD and BCL-XL $\mathrm{OE}$ in endothelial cells is shown in the Supplemental Material, Figure S10, S11.

\section{Quantification of intracellular $\mathrm{Ca}^{2+}$ concentration}

After the treatment, cells were incubated with $1 \mu \mathrm{M}$ FLUO 3/AM (Calbiochem, \# 343242), a cell-permeable $\mathrm{Ca}^{2+}$ indicator that exhibits an increase in fluorescence upon $\mathrm{Ca}^{2+}$ binding. Increase in fluorescence intensity after $\mathrm{Cd}$ treatment was detected using flow cytometry analysis (FACS Canto II, BD Biosciences) and quantified as change in the intensity as compared to the control level. We used BAPTA-AM (BMLCA411-0025, Enzo Life Sciences) at a concentration of $10 \mu \mathrm{M}$ as a sensitive intracellular $\mathrm{Ca}^{2+}$ chelator.

\section{Detection of intracellular Cd}

After treatment the cells were handled as indicated by the manufacturer's instructions (Leadmium ${ }^{\mathrm{TM}}$ Green AM Dye for intracellular Detection of Lead and Cadmium; Life Technologies, Cat.No.: 10024) and analysed by flow cytometry (FACS Canto II, BD Biosciences, Germany).

\section{Detection of changes in the mitochondrial membrane potential and staining of mitochondria}

After the treatment, cells were enzymatically detached, washed with PBS and incubated with $5 \mu \mathrm{M} \mathrm{JC}-1$ according to the manufacturer's instructions (Molecular Probes, Austria). Analysis and quantification of changes in the fluorescence intensity, indicating depolarised mitochondria, was performed using a FACS Canto II (BD Biosciences, Germany). Tracking of the cellular distribution of mitochondria in Cd-treated cells as compared to the control cells was performed using Mitotracker ${ }^{\circledR}$ Red FM and according to the manufacturer's instructions (Life Technologies, Molecular Probes).

\section{Tracking of lysosome stability}

Labelling of lysosomes was performed as previously described in Messner et al. [43]. Endothelial cells with or without an inhibitor and p $53 \mathrm{KD}$ cells were incubated with $15 \mu \mathrm{MCd}$ and $30 \mu \mathrm{M} \mathrm{Cd}$, respectively for the indicated times.

\section{Western blot analyses}

Whole protein extracts from Cd-treated and control cells were obtained by incubation of detached cells in a triple detergent lysis buffer $(50 \mathrm{mM}$ Tris-Chloride, $150 \mathrm{mM}$ Sodium Chloride, $0.02 \%$ Sodium Azide, $0.1 \%$ SDS, $1 \%$ Nonident P-40, $0.5 \%$ Sodium Deoxycholate, $5 \mu \mathrm{g} / \mathrm{ml}$ Aprotinin, $1 \mu \mathrm{g} / \mathrm{ml}$ Leupeptin, $1 \mu \mathrm{g} / \mathrm{ml}$ Pepstatin and $1 \mathrm{mM}$ ABESF). Cells were lysed by repeated freezing and thawing and subsequent sonication. After determination of protein concentration, equal amounts of proteins were separated $(20 \mu \mathrm{g})$ on SDS-polyacrylamide gels and subsequently transferred onto a nitrocellulose membrane (Schleicher and Schuell, Germany). The primary antibody used was anti-phospho S51 eIF2 alpha (ab47769; Abcam, UK; dilution: 1:750). The secondary antibody used was goat anti-rabbit IgG HRP-conjugate (\#31460, Thermo Scientific, Austria). To control loading of equal protein amounts, membranes were stained with Ponceau $\mathrm{S}$ and the GAPDH expression (ab9485; Abcam, UK, dilution 1:2500) was analysed using Western blotting (secondary antibody: goat anti-rabbit IgG HRP-conjugate \#31460, Thermo Scientific, Austria). Quantification of bands was performed using ImageJ software (National Institute of Health) and the ratios of the band intensities (GAPDH to specific eIF2 alpha S51) were calculated.

\section{Quantification of cell death}

For the analysis and quantification of Cd-induced cell death, different methods were used. Annexin V/PI staining served for the discrimination of apoptotic and necrotic cell death. The staining of the cells was performed as described in Bernhard et al. [44]. And the quantification was performed using a flow cytometry device (FACS Canto II, BD Biosciences, Germany). Annexin V and PI positive cells were summarised and quantified compared to corresponding controls to display all dead cells. Furthermore, the effect of $\mathrm{Cd}$ on the cell membrane integrity of endothelial cells was analysed by the quantification of lactate 
dehydrogenase (LDH) release using the LDH cytotoxicity kit II (Biovision) according to the manufacturer's instructions. Released LDH was quantified as compared to the LDH content of the entire cell.

\section{Detection and quantification of cellular DNA content and PI staining}

After permeabilization of cell membranes with $1 \mathrm{mg} / \mathrm{ml}$ of saponin, the DNA was stained with PI and the DNA content was then quantified by flow cytometry (FACS Canto II, BD Biosciences, Germany). Moreover, cells were cultivated in Lab Teks (BD Biosciences) and treated with 15 and $30 \mu \mathrm{M}$ $\mathrm{Cd}$, respectively for $48 \mathrm{~h}$. After fixation with $4.5 \%$ paraformaldehyde, cells were permeabilized with $0.2 \%$ Triton X-100 and cell nuclei were stained with PI $(1 \mathrm{mg} / \mathrm{ml})$.

\section{Scanning electron microscopic images of Cd-treated endothelial cells}

Fixation of treated cells was performed using $2.5 \%$ glutaraldehyde. Thereafter, cells were dehydrated in a graded ethanol series (70, 90, 100, 100, $100 \%$, and acetone), desiccated by critical point drying (Emitech K850; Quorum Technologies LTD, West Sussex, UK), mounted, sputtered with gold-palladium (Polaron CA 508; Fisons Instruments, Mainz-Kastel, Germany) and examined with a JEOL JSM5400 scanning electron microscope (Eching, Germany).

\section{Statistical analysis}

Primary data were tested for a Gaussian distribution and equality of variances. Equal distributed data were subjected either to student's $t$ Test or to one-sided ANOVA. Statistical analyses were performed using IBM SPSS Statistics 20.0 (SPSS Inc. USA).

\section{Results}

\section{Chelation of Cd by EGTA prevents toxicity and Cd treatment induces DNA strand breaks in endothelial cells}

Pre-treatment of $\mathrm{Cd}$ incubated endothelial cells with the $\mathrm{Ca}^{2+}$ (Calcium) chelator EGTA (ethylene glycol tetraacetic acid) significantly reduces the toxicity of this heavy metal. Quantification of flow cytometry-based Annexin V/Propidium Iodide (PI) staining revealed a significant inhibition of Cd-induced cell death by increasing EGTA concentrations after treatment with 15 or $30 \mu \mathrm{M} \mathrm{Cd}$ (Fig. 1a). To analyse the genotoxic effects of $\mathrm{Cd}$ on endothelial cells, a Comet-Assay was performed. Figure 1c shows representative images of the Comet Assay from both control and Cd-treated cells after $12 \mathrm{~h}$. The amount of Comet positive cells after $\mathrm{Cd}$ treatment was quantified and the results are displayed in Fig. 1b. Massive DNA strand breaks are observed after treatment with 15 or $30 \mu \mathrm{M} \mathrm{Cd}$. However, no influence of $\mathrm{Cd}$ on the cell cycle could be observed (Supplemental Material, Figure S5).

\section{Cd treatment provokes an increase in intracellular $\mathrm{Ca}^{2+}$ concentration}

In addition to the rapid genotoxic effect, $\mathrm{Cd}$ provokes a significant increase in intracellular $\mathrm{Ca}^{2+}$ concentration, already detectable after $1 \mathrm{~h}$ of incubation (Supplemental Material, Figure S1). Furthermore, the involvement of the $\mathrm{Ca}^{2+}$ sensitive non-lysosomal cysteine protease calpain was analysed by the usage of the calpain I and II inhibitor (MDL 28170) showing a significant inhibition of $\mathrm{Ca}^{2+}$ flux in cells treated with $15 \mu \mathrm{M} \mathrm{Cd}$, but no effect in cells treated with $30 \mu \mathrm{M} \mathrm{Cd}$ after $24 \mathrm{~h}$ (Fig. 2b). To rule out the role of p53 in Cd-induced cell death as previously suggested [43], we generated p53 KD endothelial cells to address the question of whether Cd-induced DNA breaks result in a p53-dependent cell death response. Although p53 is involved in the Cd-induced cell death pathway, a knockdown of p53 was not able to inhibit the intracellular $\mathrm{Ca}^{2+}$ flux induced by $\mathrm{Cd}$ after $24 \mathrm{~h}$ (Fig. 2a).

Involvement of BCL-XL in Cd-induced $\mathrm{Ca}^{2+}$ flux was analysed using endothelial cells overexpressing this antiapoptotic protein, and Fig. 2c shows that this overexpression is highly efficient in inhibiting $\mathrm{Ca}^{2+}$ flux. To test the hypothesis that $\mathrm{Cd}$ treatment induces a substantial release of $\mathrm{Ca}^{2+}$ from the endoplasmatic reticulum (ER), 2APB (2Aminoethoxydiphenyl borate) was used to inhibit $\operatorname{InsP}_{3}$ (Inositol 1,4,5-triphosphate)-mediated $\mathrm{Ca}^{2+}$ release. Flow cytometry-based analyses uncovered that $2 \mathrm{APB}$ incubation is not able to inhibit $\mathrm{Cd}$-induced $\mathrm{Ca}^{2+}$ flux entirely, but does so significantly as observed $24 \mathrm{~h}$ after treatment with $30 \mu \mathrm{M}$ (Fig. 2d). Referring to the controversially discussed specificity of $2 \mathrm{APB}$ as restricted to $\mathrm{ER} \mathrm{Ca}^{2+}$ pumps, we analysed the effect of this inhibitor upon the cellular $\mathrm{Cd}$ uptake. Leadmium-dye-based intracellular $\mathrm{Cd}$ quantification indicates that 2APB significantly inhibits Cd uptake (Fig. 2e).

\section{Cd treatment induces mitochondrial membrane depolarisation and changes in the mitochondrial distribution}

Further in-depth characterisation of Cd-induced cell death signals uncovered an involvement of the mitochondria. Treatment of endothelial cells with $15 \mu \mathrm{M} \mathrm{Cd}$ as well as $30 \mu \mathrm{M} \mathrm{Cd}$ provokes a significant depolarisation of the mitochondria over an incubation period of $72 \mathrm{~h}$ (Fig. 3). As 

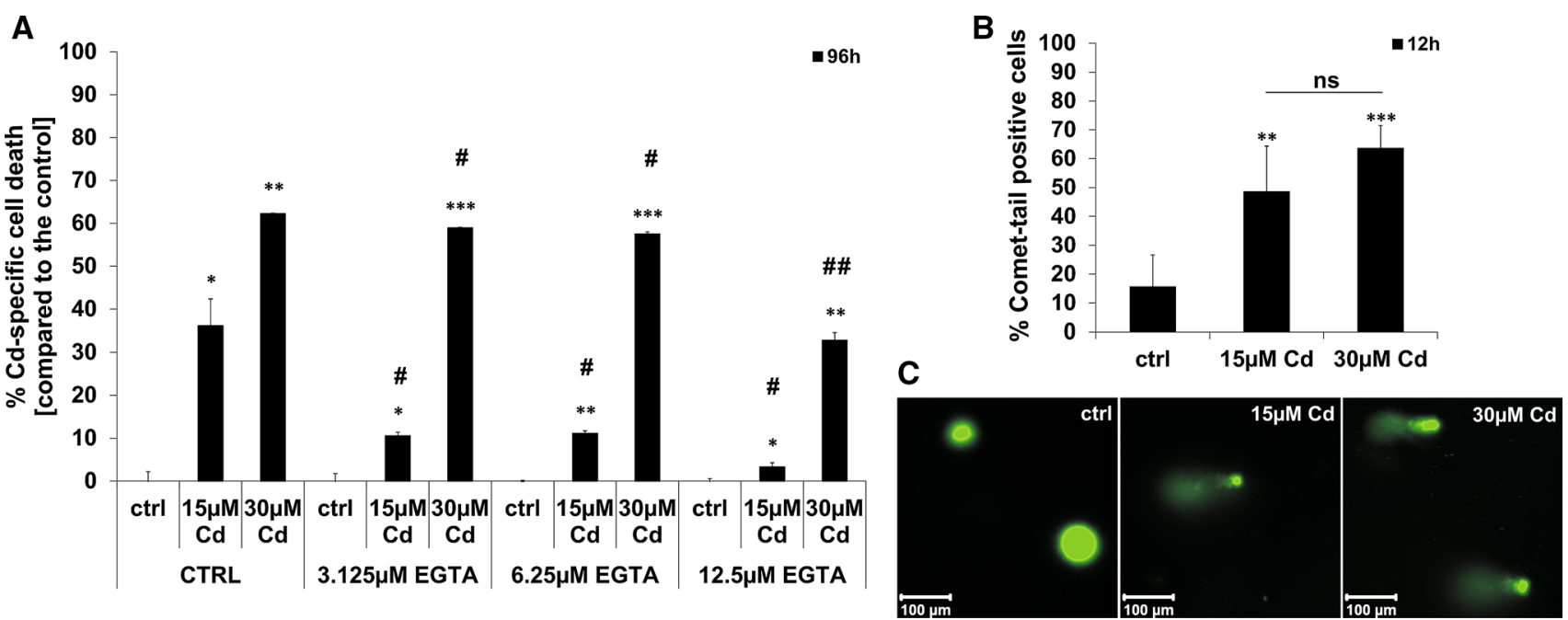

Fig. 1 Inhibition of $\mathrm{Cd}$ toxicity by EGTA and the effect of $\mathrm{Cd}$ on endothelial DNA. a Shows the quantification of Cd-induced cell death (Annexin V/PI staining) after pre-treatment of cells with increasing EGTA concentrations. (b) Quantification of Comet-tail positive endothelial cells after treatment with 15 and $30 \mu \mathrm{M} \mathrm{Cd}$ for $12 \mathrm{~h}$. (c) Representative images of cell nuclei stained with SYBR green. All

calpains are also present in the mitochondria, the effect of the calpain inhibitor on mitochondrial depolarisation was tested. Figure $3 \mathrm{a}$ shows that the calpain inhibitor was efficient in inhibiting the depolarisation after treatment with 15 and $30 \mu \mathrm{M} \mathrm{Cd}$ over a period of $72 \mathrm{~h}$. A stable overexpression of the anti-apoptotic protein BCL$\mathrm{XL}$ was able to inhibit mitochondrial depolarisation although the effect is less pronounced as compared to the effect of the calpain inhibitor (Fig. 3b). A similar inhibitory effect on mitochondrial depolarisation was detected in cells with a stable p53 knock-down (KD) (Fig. 3c). Furthermore, chelation of $\mathrm{Ca}^{2+}$ by the chelating agent BAPTA completely inhibits mitochondrial depolarisation induced by $15 \mu \mathrm{M} \mathrm{Cd}$ after $48 \mathrm{~h}$, but showed no effect after treatment with $30 \mu \mathrm{M} \mathrm{Cd}$ or after a longer Cd exposure (up to $72 \mathrm{~h}$ ). However, this effect can be explained by the celltoxic effect of BAPTA treatment itself (Fig. 3d). A detailed analysis of mitochondrial structure revealed severe $\mathrm{Cd}$ dependent effects on mitochondrial mass (Fig. 3e, $15 \mu \mathrm{M}$ ) and integrity (Fig. 3e, $30 \mu \mathrm{M}$ ). This strongly suggests that Cd-induced cell death is mediated by mitochondria integrity.

\section{Lysosomal membrane permeabilization and induction of autophagy signals are characteristic of death signalling in Cd-treated endothelial cells}

As already reported by our group, $\mathrm{Cd}$ treatment of endothelial cells induces autophagy signals (namely, an experiments were performed in triplicates and were repeated at least three times. Results depict the mean \pm standard deviation. Asterisks indicate significant differences compared to the corresponding control $(* p<0.05 ; * * p<0.01, * * * p<0.001)$ and hash signs indicate significant differences between the groups $\left({ }^{\#} p<0.05 ;{ }^{\# \#} p<0.01\right)$; $n s$ not significant

increase in LC3 I to LC3 II ratio). As the lysosomes are involved in autophagy signalling, we analysed stability of these organelles using flow cytometry techniques which show a strong Cd-dependent disruption of lysosome integrity (Fig. 4). Moreover, Fig. 4a shows that the stable knock-down of p53 is able to completely inhibit lysosomal degradation after treatment with $15 \mu \mathrm{M}$ Cd over a time period of $96 \mathrm{~h}$ as well as in cells incubated with $30 \mu \mathrm{M} \mathrm{Cd}$ over $72 \mathrm{~h}$. In contrast, inhibition of calpain protease or autophagy (3MA) failed to exert lysosomeprotective characteristics (Supplemenatl Material, Figure S6 A, B). In response to the unfolded protein response (UPR) (also a part of autophagy signalling) within the ER, the function of eukaryotic initiation factor eIF2 alpha is inhibited by phosphorylation. Western blot-based analyses showed a phosphorylation of eIF2 alpha in response to $\mathrm{Cd}$ treatment (Fig. 4b).

\section{Classical AnnexinV/PI based flow cytometry analyses reveal apoptosis as the prevailing mode of Cd-induced cell death}

Flow cytometry-based analyses uncovered apoptosis as the prevailing cell death mode. After $72 \mathrm{~h}$ of treatment with $15 \mu \mathrm{M} \mathrm{Cd}$, nearly equal numbers of cells are dying by apoptosis and necrosis. Treatment with a higher $\mathrm{Cd}$ concentration of $30 \mu \mathrm{M}$ induces a marked increase in the amount of apoptotic cells. Prolonged treatment with $15 \mu \mathrm{M}$ Cd over a time period of $96 \mathrm{~h}$ enhances necrotic and, to a greater extent, apoptotic cell death (Fig. 5a). 
Fig. $2 \mathrm{Cd}$ induced increase in cytosolic $\mathrm{Ca}^{2+}$ concentration. a-d show flow cytometry-based quantifications of intracellular $\mathrm{Ca}^{2+}$ concentration after $\mathrm{Cd}$ treatment of endothelial cells for the indicated times. The effect of p53 KD (a), the incubation with calpain inhibitor (b), overexpression of BCL-XL (c), and of the incubation with $2 \mathrm{APB}$

(d) on cytosolic $\mathrm{Ca}^{2+}$

concentration is also depicted. e Shows flow cytometry-based analyses of the effect of 2APB on endothelial $\mathrm{Cd}$ uptake after $96 \mathrm{~h}$. All experiments were performed in triplicates and were repeated at least three times. Results depict the mean \pm standard deviation. Asterisks indicate significant differences compared to the corresponding $(* p<0.05$; $* * p<0.01)$ and hash signs indicate significant differences between the groups $\left({ }^{\#} p<0.05\right.$; $\left.{ }^{\# \#} p<0.01\right)$
A

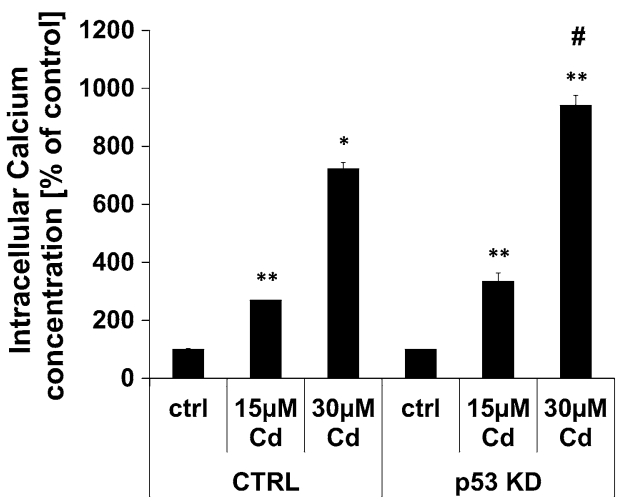

C

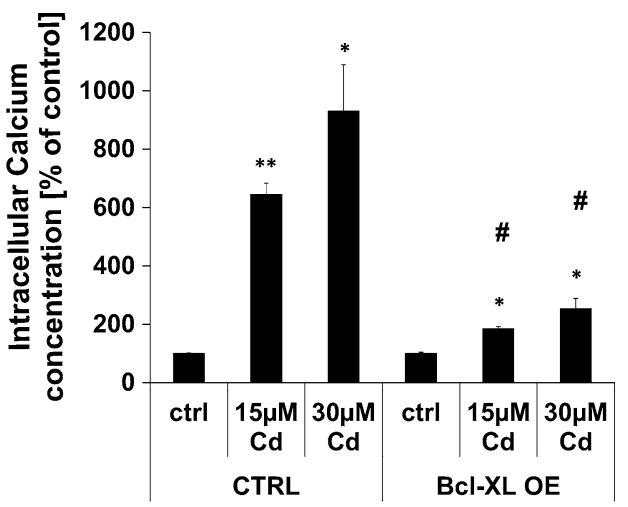

B

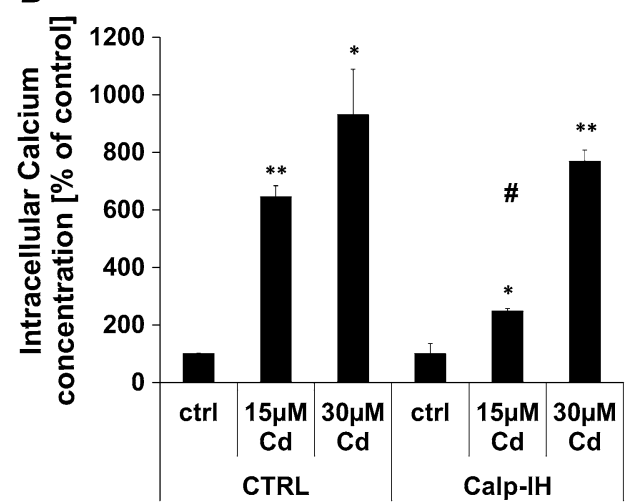

D

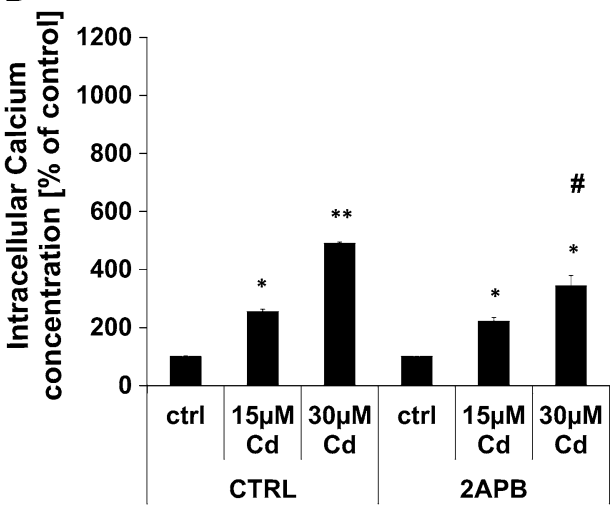

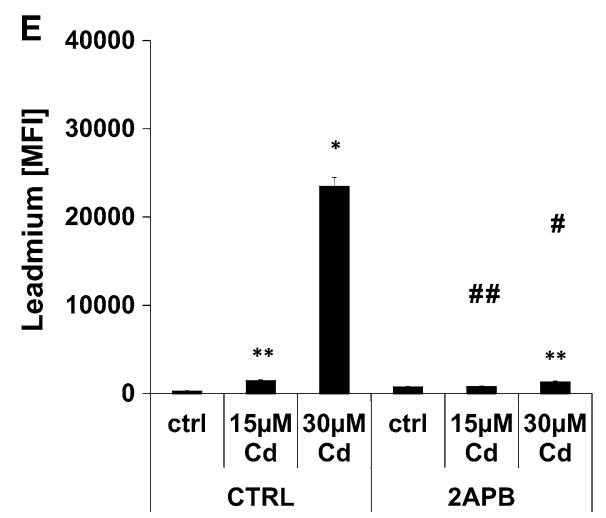

Figure $5 \mathrm{~b}$ depicts the calpain inhibitor's ability to reduce the amount of dead cells after treatment with 15 and $30 \mu \mathrm{M} \mathrm{Cd}$ for $72 \mathrm{~h}$. Likewise, the stable knock-down of p53 is able to prevent Cd-induced death over $72 \mathrm{~h}$, where the effect of the knock-down is stronger than the effect of the calpain inhibitor (Fig. 5c). Overexpression of the antiapoptotic protein BCL-XL has only a minor inhibiting effect upon cell death, yet the effect is nonetheless statistically significant at both concentrations (Fig. 5d). Neither inhibition of autophagy with 3MA (Fig. 5e) nor energy supplementation (Supplemental Material,
Figure S9 A-C) protects cells treated with $15 \mu \mathrm{M} \mathrm{Cd}$. However, we observed an almost-significant increase of viability in $30 \mu \mathrm{M}$ Cd-treated cells ( $p=0.079$; Fig. 5e). Based on the controversial results obtained with $2 \mathrm{APB}$ (partial inhibition of $\mathrm{Ca}^{2+}$ flux and inhibition of $\mathrm{Cd}$ uptake), the effect of this inhibitor on Cd-induced cell death was assessed. 2APB was able to completely inhibit death of cells treated with $15 \mu \mathrm{M} \mathrm{Cd}$ and showed the most potent cell death inhibitory effect in cells treated with $30 \mu \mathrm{M} \mathrm{Cd}$ as compared to all other inhibitors, knockdowns and over-expressions (Fig. 5f). 
Fig. 3 Cd impairs

mitochondrial membrane

potential and reduces

mitochondrial mass. Flow

cytometry-based analyses of

mitochondrial membrane

potential in Cd-treated

endothelial cells are shown in

(a-d). Cd-treated endothelial

cells were incubated either with

the calpain inhibitor or BAPTA

and mitochondrial membrane

potential was assayed using a

JC-1 assay and quantified by

flow cytometry analyses $(\mathbf{a}, \mathbf{d})$.

b, c The effects of either p53

$\mathrm{KD}$ or BCL-XL OE on

mitochondrial membrane

potential in Cd-treated

endothelial cells. e The first row

shows representative images of

Cd-treated endothelial cells

(48 h) stained with MitoTracker

Red and the second row shows

magnifications indicated by the

corresponding white boxes. All

experiments were performed in

triplicates and were repeated at

least three times. Results depict

the mean \pm standard deviation.

Asterisks indicate significant

differences compared to the

corresponding $\left({ }^{*} p<0.05\right.$;

$* * p<0.01, * * * p<0.001)$ and

hash signs indicate significant

differences between the groups

$\left({ }^{\#} p<0.05 ;{ }^{\# \#} p<0.01\right)$
A $\overline{\overline{0}}$
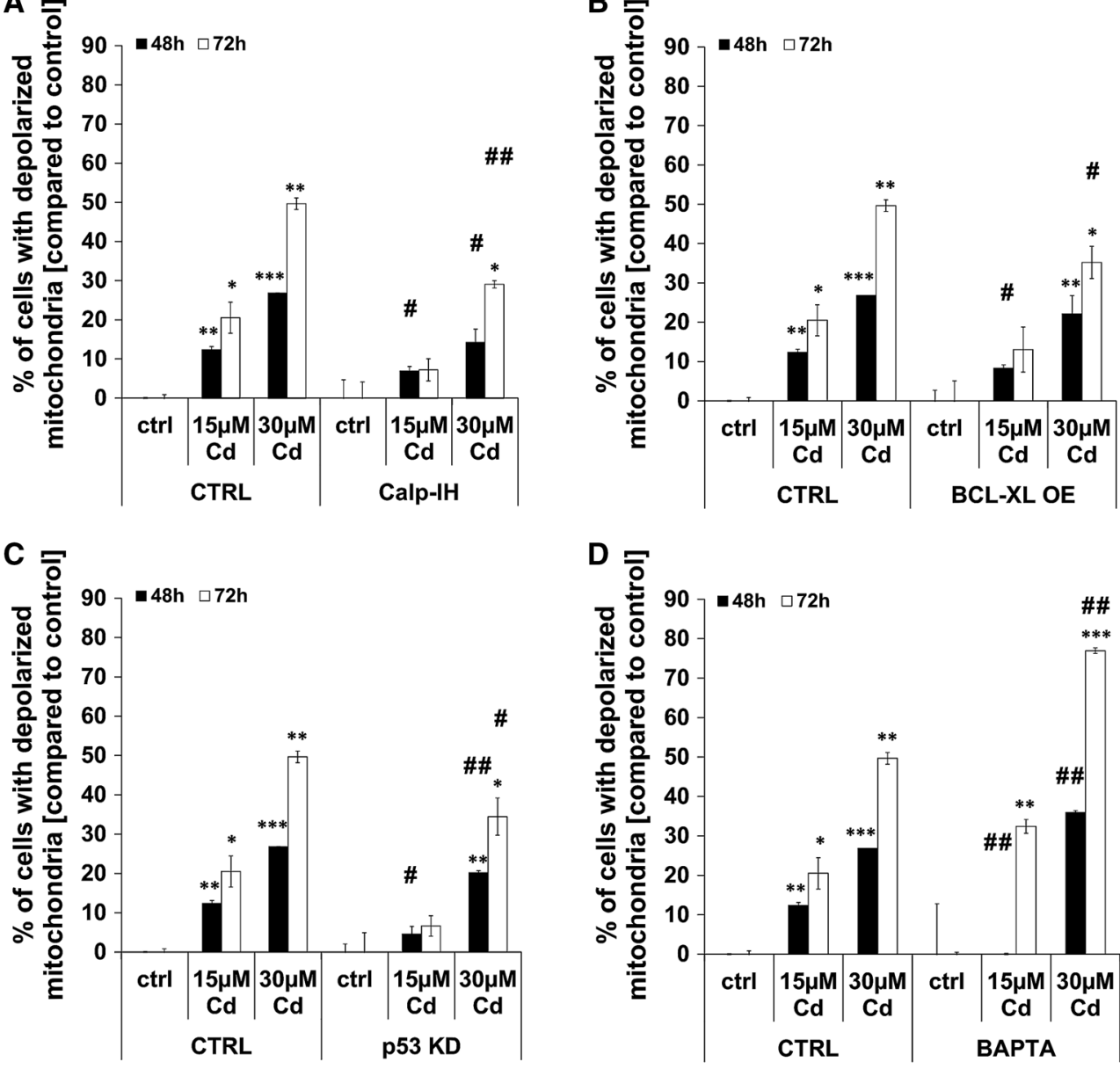

E
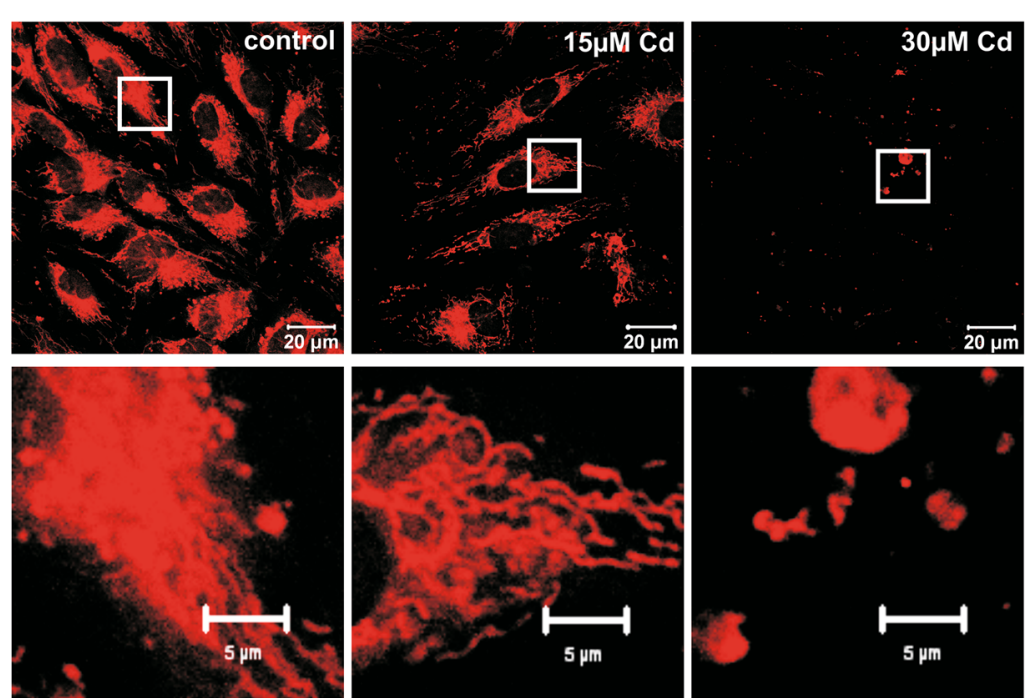

$\mathrm{D} \overline{\mathrm{g}}$

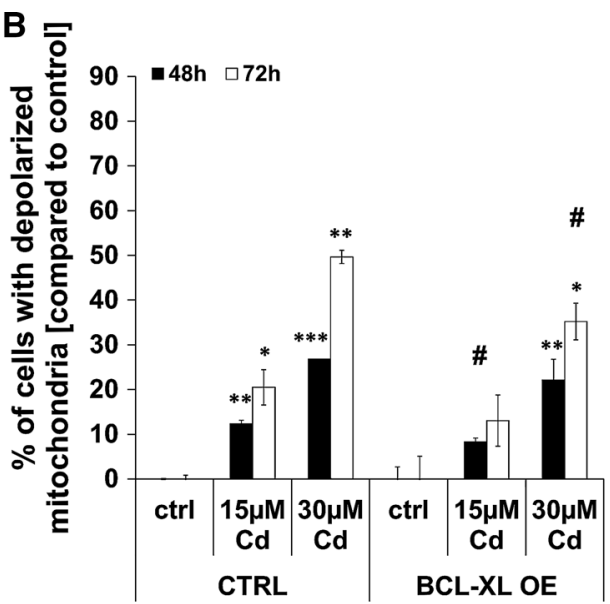

\section{*}

DNA degradation is characteristic of end-stage processes of $\mathrm{Cd}$-induced endothelial cell death

In contrast to the flow cytometry-based analyses of Annexin V/PI stainings, measurement of DNA content in 


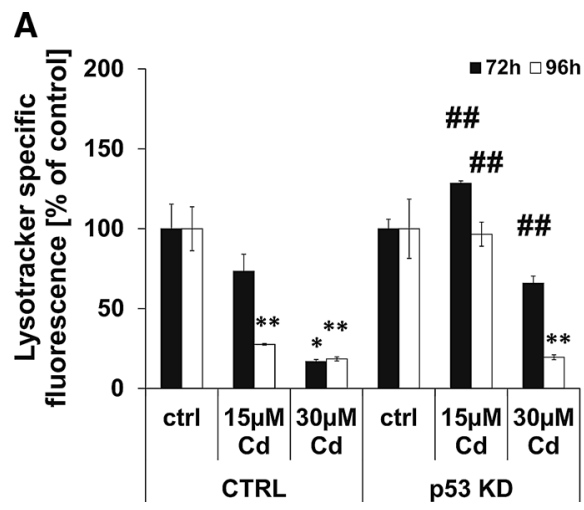

Fig. 4 Cd-induced lysosomal membrane permeabilization and eIF2 alpha phosphorylation. Flow cytometry-based quantification of LMP was performed in endothelial cells treated with 15 and $30 \mu \mathrm{M} \mathrm{Cd}$ for 72-96 h. The effect of the p53 KD on Cd-induced LMP is depicted in (a). Western Blot-based analyses of eIF2 alpha phosphorylation in endothelial cells after $\mathrm{Cd}$ treatment is depicted (b). To compensate unequal protein loading, the Ponceau staining of membranes as well

visible after treatment with $30 \mu \mathrm{M} \mathrm{Cd}$, despite the effect only being significant after $48 \mathrm{~h}$ (with a non-significant trend observed after 72 and 96 h; Fig. 6a). Overall, no inhibitory effect on Cd-induced DNA degradation could be observed after the pre-incubation with the calpain inhibitor and the autophagy inhibitor (Supplemental Material, Figure S7 A, B). Moreover, the pre-incubation of Cd-treated cells with the $\mathrm{Ca}^{2+}-\mathrm{Mg}^{2+}$-dependent endonuclease inhibitor Aurintricarboxylic acid (ATA) does not abolish the progressive DNA degradation (Supplemental Material, Figure S8A). However, incubation with the extracellular $\mathrm{Ca}^{2+}$ chelator EGTA prevents Cd-induced DNA degradation completely (Supplemental Material, Figure S8B). Figure $6 \mathrm{~b}$ depicts images of stained cell nuclei of control and Cd-treated cells after $48 \mathrm{~h}$ of incubation. Control cells show intact cell nuclei containing DNA, whereas the nuclei of Cd-treated cells show reduced DNA content to almost complete degradation.

\section{Cd induces the permeabilization of the plasma membrane and release of $\mathrm{LDH}$}

Further confirmation of necrosis as the final outcome of Cd-induced endothelial cell death is the permeabilization of the plasma membrane, shown by a massive LDH release and through scanning electron microscopic-images (Fig. 7). LDH release induced by $15 \mu \mathrm{M} \mathrm{Cd}$ could be significantly suppressed by inhibition of calpain activity, 3MA incubation, p53 KD and the combination of the calpain inhibitor with 3MA. LDH release induced by $30 \mu \mathrm{M}$ $\mathrm{Cd}$ is inhibited neither by the previously mentioned inhibitors nor by a knock-down of p53. Furthermore, a combination of $\mathrm{p} 53 \mathrm{KD}$ and the individual inhibitors was not effective in inhibiting membrane permeabilization.

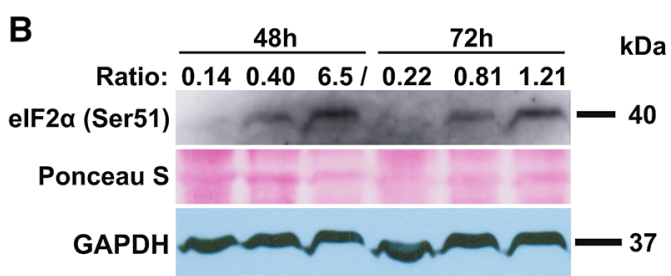

as the GAPDH expression is shown and the ratio between specific signal intensity and protein loading (GAPDH) was calculated and depicted. All experiments were performed in triplicates and were repeated at least three times. Results depict the mean \pm standard deviation. Asterisks indicate significant differences compared to the corresponding control $(* p<0.05 ; * * p<0.01)$ and hash signs indicate significant differences between the groups $\left({ }^{\# \#} p<0.01\right)$

However, the combined treatment of p53 KD endothelial cells with the calpain inhibitor and 3MA completely abolishes LDH release in cells treated with $15 \mu \mathrm{M} \mathrm{Cd}$ and reduces the amount of $\mathrm{LDH}$ released from cells treated with $30 \mu \mathrm{M} \mathrm{Cd}$ to below $21 \%$ of the control level (Fig. 7a). To illustrate the Cd-induced effects on the endothelial cell surface, scanning electron microscopic images were taken and are depicted in Fig. 7b. Shown are wild-type endothelial cells (CTRL) treated with $\mathrm{Cd}$ and p53 KD cells incubated with the calpain inhibitor and 3MA. Untreated cells show a flattened shape with an intact plasma membrane and the location of the nucleus is clearly visible. CTRL cells treated with $15 \mu \mathrm{M} \mathrm{Cd}$ exhibit blebs of different size on their surface (labelled with stars) and in addition several leaks in the plasma membrane (labelled with arrows). Moreover, shrinkage of these cells is observable. In contrast, p53 KD cells incubated with the calpain inhibitor and 3MA, and treated with $15 \mu \mathrm{M} \mathrm{Cd}$ are completely intact. Wild-type cells incubated with $30 \mu \mathrm{M}$ $\mathrm{Cd}$ exhibit a large number of blebs of different sizes (labelled with stars) and the plasma membrane appears to be completely disintegrated (labelled with stars). As expected from the results of the LDH assay, p53 KD cells incubated with the calpain inhibitor and 3MA and treated with $30 \mu \mathrm{M}$ Cd showed a slight detachment from the surface and only a few small holes in the membrane (Fig. 7b).

\section{Discussion}

The chelating agents EGTA and EDTA (ethylenediamineteteaacetic acid) which are clinically applied for the treatment of metal intoxications clearly reduce $\mathrm{Cd}$-induced DNA degradation in a concentration-dependent manner by 
Fig. 5 Cd treatment results in apoptotic as well as necrotic cell death in endothelial cells.

Endothelial cells were treated with $\mathrm{Cd}$ as indicated for 72 and $96 \mathrm{~h}$ and the amount of necrotic as well as apoptotic cells were quantified using Annexin V/PI stainings and flow cytometrybased analyses (a). The cell death inhibitory effect of the calpain inhibitor (b), p53 KD (c), BCL-XL OE (d), autophagy inhibition (e) and of $2 \mathrm{APB}(\mathbf{f})$ is also depicted in this figure. All experiments were performed in triplicates and were repeated at least three times. Results depict the mean \pm standard deviation. Asterisks indicate significant differences compared to the corresponding control $(* p<0.05 ; * * p<0.01$, $* * * p<0.001)$ and hash signs indicate significant differences between the groups $\left({ }^{\#} p<0.05\right.$; $\# p<0.01 ; \ldots$
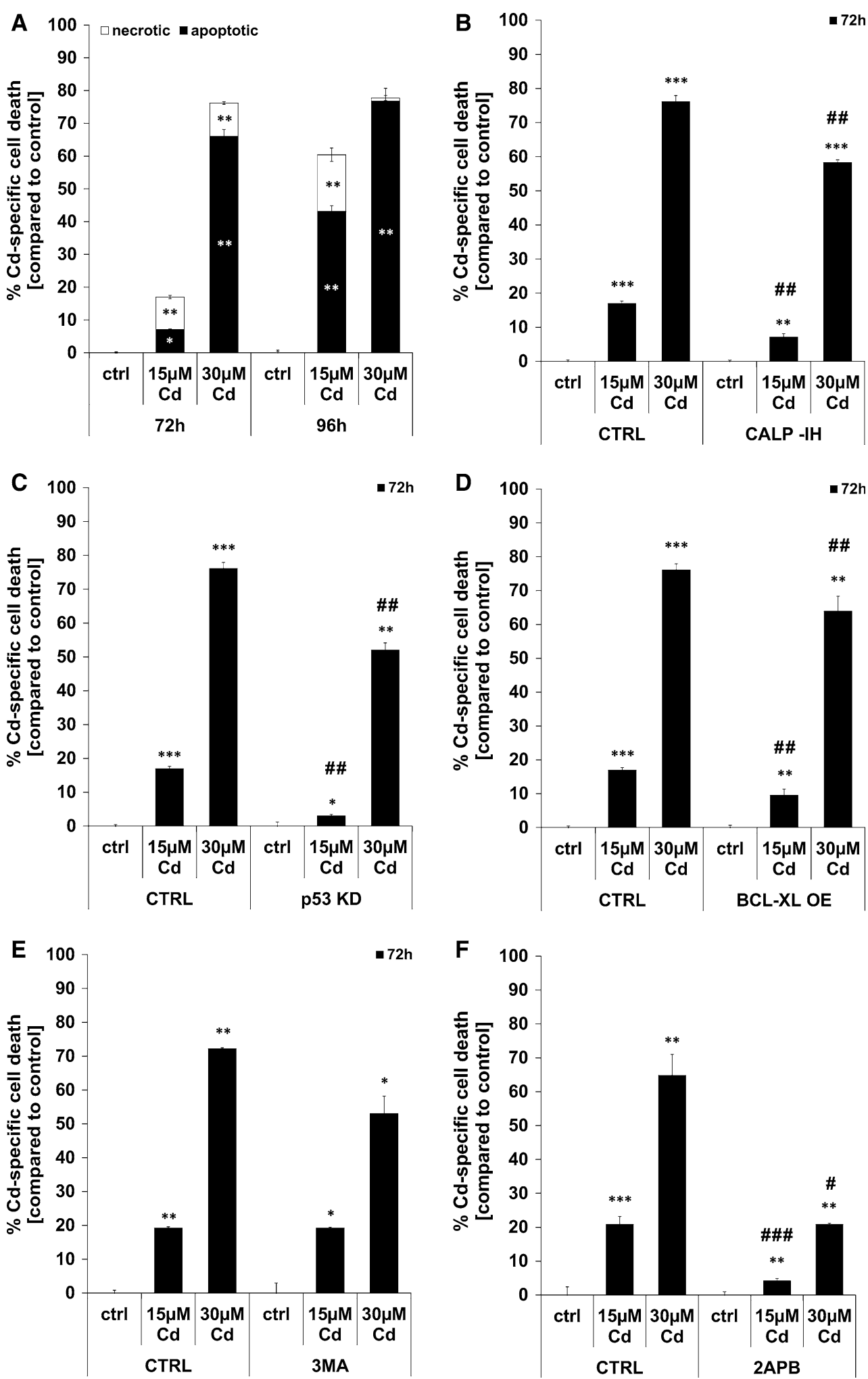

forming extracellular complexes with the metal ion, thereby hindering the cellular uptake of $\mathrm{Cd}$. [45] Once taken up by cells, $\mathrm{Cd}$ is known to cause DNA damage as already proven in different cell types such as liver cells [46,
47], fibroblasts [48], lung cells [49], and epithelial cells [50]. Similarly, endothelial cells are also sensitive to $\mathrm{Cd}-$ induced DNA damage as demonstrated by our previous data showing an increase in the expression of the DNA 
Fig. $6 \mathrm{Cd}$ treatment of endothelial cells provokes complete DNA degradation. Endothelial cells were treated with 15 and $30 \mu \mathrm{M} \mathrm{Cd}$ for 48 and $72 \mathrm{~h}$ and the cellular DNA content was quantified in permeabilized cells using PI staining and flow cytometrybased analyses. The effect of p53 KD on Cd-induced DNA degradation is shown in (a). b Representative images of the PI stained endothelial nuclei after Cd treatment for $48 \mathrm{~h}$. All experiments were performed in triplicates and were repeated at least three times. Results depict the mean \pm standard deviation. Asterisks indicate significant differences compared to the corresponding control $(* p<0.05 ; * * p<0.01$, $* * * p<0.001)$ and hash signs indicate significant differences between the groups $\left({ }^{\#} p<0.05\right.$; ${ }^{\# \#} p<0.01$ )

\section{A}

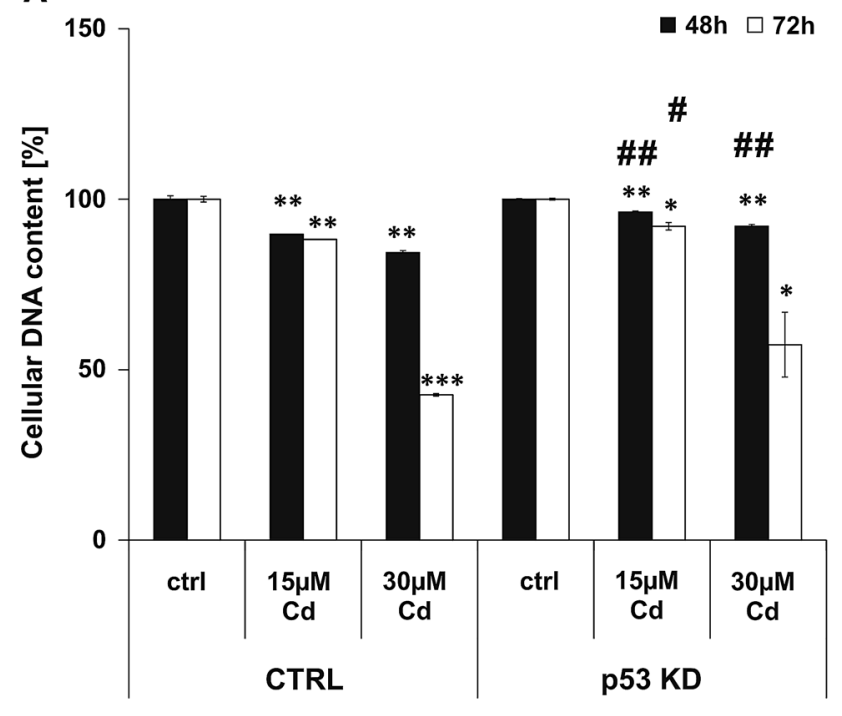

B

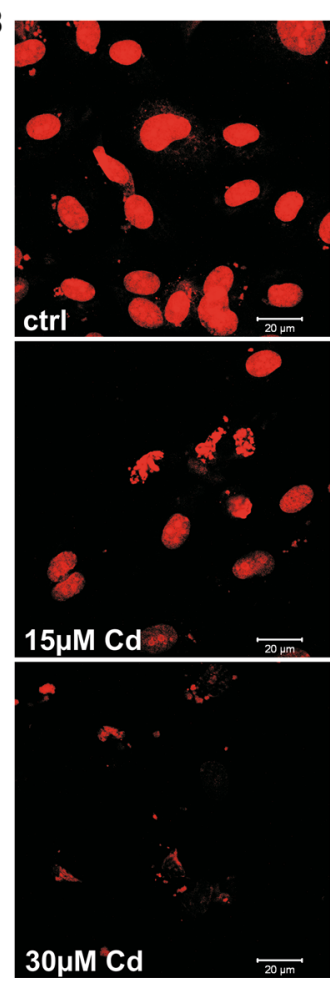

damage response protein p53 [29] and the latest data showing a pronounced amount of Comet-positive cells after $12 \mathrm{~h}$ of $\mathrm{Cd}$ treatment. Interestingly, the extent of damage is comparable between 15 and $30 \mu \mathrm{M} \mathrm{Cd}$, although the number of dead cells is significantly higher after treatment with $30 \mu \mathrm{M} \mathrm{Cd}$. Furthermore, the involvement of DNA damage and p53 in Cd-induced cell death signalling is shown by the inhibition of cell death (and the preservation of proliferation after $\mathrm{Cd}$ treatment, Supplemental Material, Figure S3 A, B) after the knock-down of p53. This demonstrates that $\mathrm{Cd}$ causes DNA damage in endothelial cells even at lower concentrations leading to cell death with the involvement of p53.

In addition to the induction of DNA damage, Cd treatment of endothelial cells induces a rapid and substantial increase in intracellular $\mathrm{Ca}^{2+}$ concentration within $6 \mathrm{~h}$. $\mathrm{Ca}^{2+}$, as a universal intracellular messenger, influences a wide range of cellular processes (such as cell death signalling) when the concentration is elevated in the cytosolic compartment $[51,52]$. Cytosolic $\mathrm{Ca}^{2+}$ increase is accomplished by either uptake from the extracellular space or release from intracellular $\mathrm{Ca}^{2+}$ stores such as the ER and the mitochondria. 2APB, a critically discussed blocker of $\mathrm{Ca}^{2+}$ release from the ER, reduces Cd-induced cytosolic $\mathrm{Ca}^{2+}$ concentration but simultaneously inhibits both cellular $\mathrm{Cd}$ uptake and $\mathrm{Cd}$-induced cell death significantly. Moreover, chelation of extracellular $\mathrm{Ca}^{2+}$ by EGTA protects endothelial cells from $\mathrm{Cd}$-induced cell death. $\mathrm{Ca}^{2+}$ concentration showed no link to p53-dependent DNA damage signalling. Another indication of the release of $\mathrm{Ca}^{2+}$ from the ER through $\mathrm{Cd}$ treatment is the fact that the over-expression of BCL-XL-an anti-apoptotic BCL-2 family member located in the ER membrane-is able to inhibit the increase of cytosolic $\mathrm{Ca}^{2+}$ concentration in endothelial cells. However, BCL-XL OE did not effectively prevent endothelial cell death following $\mathrm{Cd}$ incubation. Withe and $\mathrm{Li}$ et al. confirmed this hypothesis by providing evidence of a regulation of the inositol trisphosphate receptor $\left(\mathrm{InsP}_{3} \mathrm{R}\right)$ by BCL-XL through direct interaction to increase apoptosis resistance [53]. Transmission of the cell death signal from $\mathrm{Ca}^{2+}$ is mediated by a family of $\mathrm{Ca}^{2+}$-dependent non-lysosomal cysteine proteases known as calpains [54]. Interestingly, inhibition of calpain activity reduces intracellular $\mathrm{Ca}^{2+}$ concentration significantly at low $\mathrm{Cd}$ concentrations. Although an involvement of autophagy in Cd-induced endothelial cell death is already proven [43], no interplay between increased cytosolic $\mathrm{Ca}^{2+}$ and autophagy could be detected.

The complex signalling pathway is extended by an involvement of the mitochondria and a variety of factors influencing mitochondrial function [29]. Depolarisation of mitochondria as well as the simultaneous loss of mitochondrial mass certainly occurs late in the Cd-induced cell death process (after $48 \mathrm{~h}$ ). Similarly to p53-mediated cell death in neuronal cells [55], Cd toxicity leads to mitochondrial depolarisation through $\mathrm{p} 53$, which was reduced 


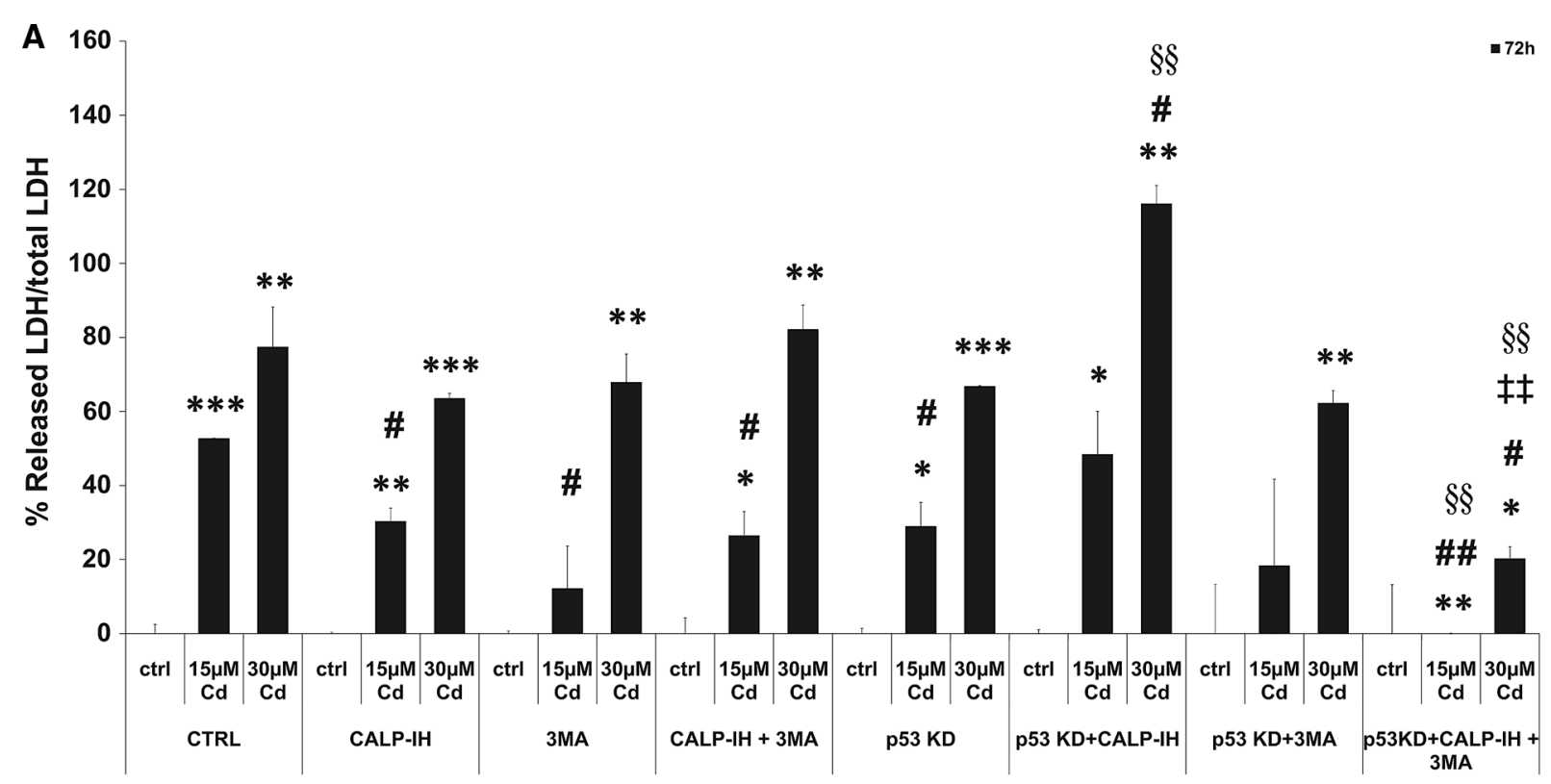

B ctrl

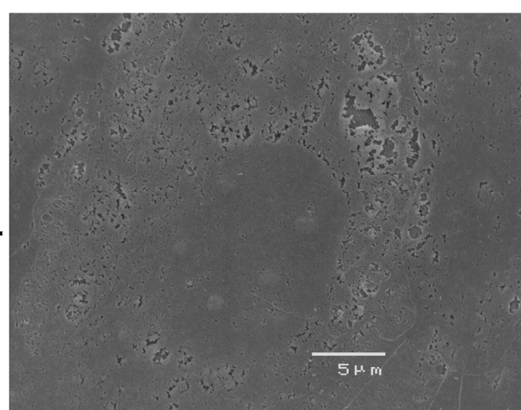

\section{CTRL}

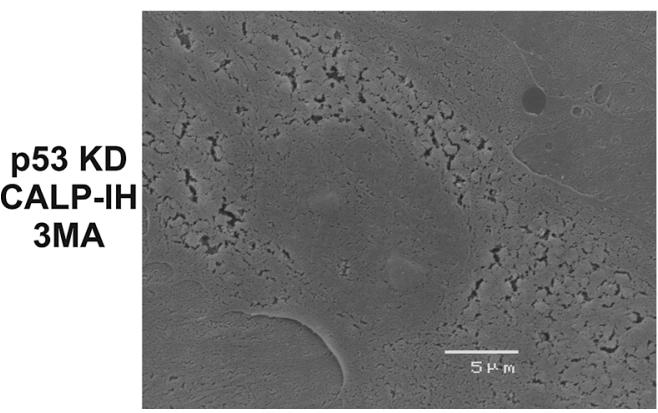

$15 \mu \mathrm{M} \mathrm{Cd}$
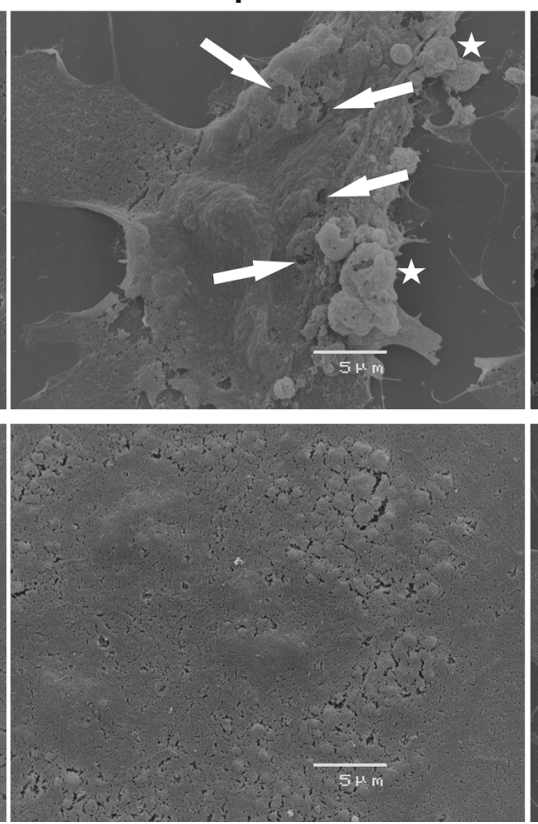

$30 \mu \mathrm{M} \mathrm{Cd}$
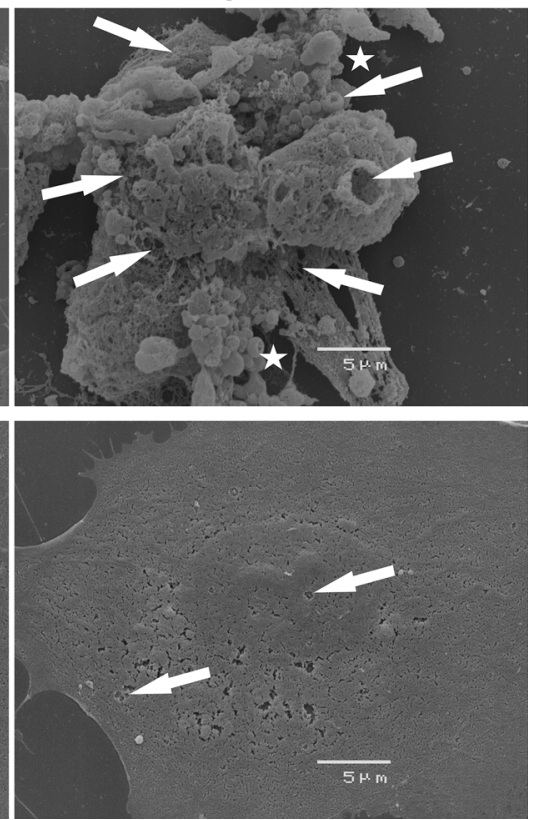

Fig. $7 \mathrm{Cd}$ induced membrane permeabilization and LDH release. a The analyses of Cd-induced LDH release from endothelial cells into the cell culture supernatant as well as the effects of inhibitors (calpain inhibitor and 3MA) and p53 KD and also their combined effect. Representative scanning electron microscopic images of wild-type endothelial cells treated with $\mathrm{Cd}$ and $\mathrm{p} 53 \mathrm{KD}$ cells pre-incubated with the calpain inhibitor and 3MA treated with $\mathrm{Cd}$ are shown (stars indicate membrane blebs and arrows mark holes in the plasma membrane) (b). All experiments were performed in triplicates and

by the $\mathrm{p} 53 \mathrm{KD}$. Since outer membrane permeabilization is weakly inhibited by BCL-XL OE, Bax activation is arguably involved in mitochondrial depolarisation. Additionally, Cd-induced mitochondrial depolarisation is were repeated at least three times. Results depict the mean \pm standard deviation. Asterisks indicate significant differences compared to the corresponding control (ctrl; $* p<0.05 ; * * p<0.01$, *** $p<0.001$ ), hash signs indicate significant differences compared to the control group without the inhibitor or KD (CTRL; ${ }^{\#} p<0.05$; ${ }^{\#} p<0.01$;

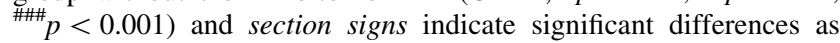
between the p53 cells without the inhibitor and p53KD cells with the inhibitor $\left({ }^{\S} p<0.01\right)$

also indirectly induced by calpain activation (as already shown in endothelial cells [55]) as well as directly through elevated $\mathrm{Ca}^{2+}$ levels as indicated by the limited inhibitory effect of intracellular $\mathrm{Ca}^{2+}$ chelation. Lastly, the close 
proximity between ER cisternae and the mitochondria allows for local $\mathrm{Ca}^{2+}$ oscillation into mitochondria [56]. All these factors ultimately lead to a central element in apoptosis, which is signal transduction through caspases, known as apoptosis executors. In the case of Cd-treated endothelial cells we have previously shown that caspase-3 is cleaved, but $\mathrm{Cd}$ inhibits its activity [29]. Therefore, the apoptotic signalling is halted at this point, underpinned by unchanged intracellular ATP concentration (Supplemental Material, Figure S2).

$\mathrm{Ca}^{2+}$ imbalance and calpain activation not only lead to mitochondrial signalling but also result in the initiation of

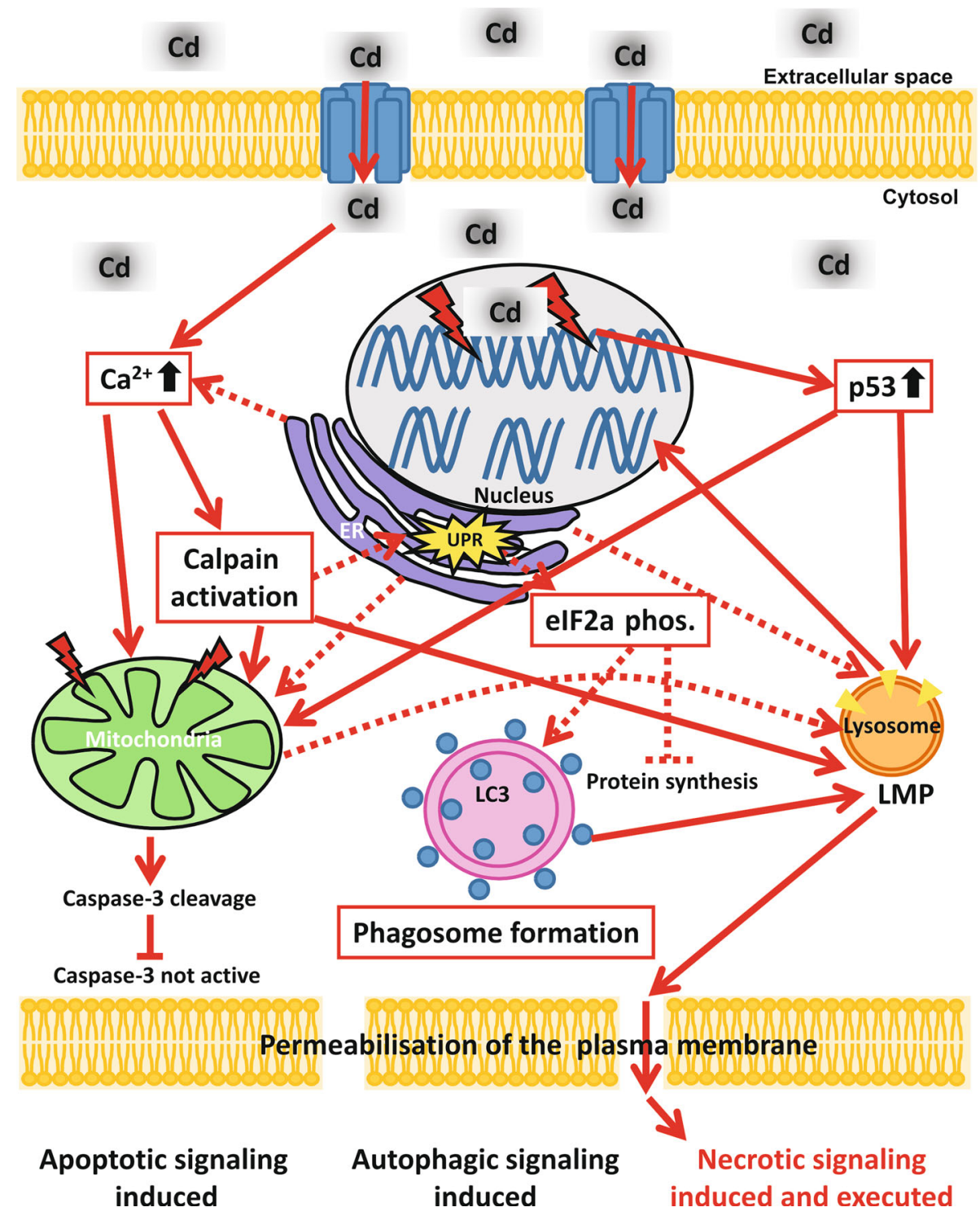

Fig. 8 Schematic representation of Cd-induced signalling pathways in endothelial cells. After uptake of $\mathrm{Cd}$ in endothelial cells [possibly through divalent metal transporter 1 (DMT-1)] the cytosolic $\mathrm{Ca}^{2+}$ concentration rises. Besides being taken up from the extracellular space, $\mathrm{Ca}^{2+}$ could also originate from the ER. Redirection of the signal to the mitochondria could take place directly by $\mathrm{Ca}^{2+}$ or also indirectly by the activation of calpains. Forwarding of the apoptotic signalling from the mitochondria occurs via the cleavage of caspase-3, but the apoptotic signal is halted at this point as Cd treatment is known to simultaneously inhibit caspase-3 activity. Alongside affecting the mitochondria, $\mathrm{Cd}$ treatment impairs also the ER function and induces ER stress (shown by UPR). Cd-induced ER stress may stop protein synthesis via eIF2 alpha phosphorylation and also induce autophagic signalling, potentially as a survival mechanism. An additional target of Cd-induced toxicity in endothelial cells is cellular DNA. Cd-induced DNA damage results in upregulation of the DNA damage response protein $\mathrm{p} 53$, which in turn is shown to influence mitochondrial membrane potential. The central organelle in Cd-induced toxicity is the lysosome, as Cd-induced death signals from the mitochondria, the ER and p53 are finally "merging" at the lysosome, inducing LMP. LMP induction is in consequence responsible for complete DNA degradation and also for plasma membrane permeabilization and therefore ultimately for the execution of necrosis in Cd-treated endothelial cells although apoptotic as well as autophagy signals are triggered as well 
the UPR and induce ER stress, indicated by the phosphorylation of eIF2 alpha. Phosphorylation of eIF2 alpha disables initiation of translation and thereby inhibits the production of novel unfolded proteins to reduce ER stress. If this protective feedback loop fails, apoptotic signalling is induced-likely, once again, via the mitochondria [57]. Importantly, the PERK-eIF2 alpha complex is responsible for the up-regulation of Atg12 and thereby induces autophagosome formation. The induction of autophagy signals by $\mathrm{Cd}$ treatment, shown by an increased LC3 II/LC3 I ratio [43] as well as cell death protection through 3MA incubation, might therefore be triggered by UPR and eIF2 alpha phosphorylation. However, autophagy is inhibited since Cd treatment of endothelial cells provokes lysosomal membrane permeabilization (LMP) [43].

Lysosomes are known as "suicide bags" indicating their role in both cell death mainly through necrosis but also in survival mechanisms in the case of autophagy [58]. As previously described, Cd-induced LMP provokes the release of nucleases triggering complete DNA degradation, as well as proteases and lipases causing permeabilization of the plasma membrane [43]. Previously, BCL-XL OE demonstrated a stabilizing effect on LMP which suggests the involvement of the mitochondria [43]. An explanation of this effect could be the fact that BCL-XL attenuates BAX activity, a pro-apoptotic protein which is known to induce LMP. Moreover, as BCL-XL is also present in the ER-membrane, an involvement of this organelle in LMP cannot be excluded. Lastly, we were able to provide a connection between a DNA damage-induced increased expression of p53 and LMP, as the knock-down of p53 rescues cells from Cd-induced LMP, which is already shown in myeloid leukaemic cells [59]. The signalling cascade from increased p53 protein levels to LMP is further confirmed by the protection of DNA degradation and the inhibition of plasma membrane rupture by p53 KD. In contrast to data from neuronal cells by Villalpando Rodriguez et al. [60], in endothelial cells no connection between calpain activation, LMP induction and DNA degradation could be observed. However, an inhibition of calpain activity inhibits cell membrane permeabilization and preserves proliferation (Supplemental Material, Figure S4 A, B), possibly through an as yet unknown mechanism. Comparable to the inhibition of calpain activity and the knock-down of p53, the disruption of autophagy signals also inhibits plasma membrane permeabilization. Remarkably, an inhibition of apoptotic signalling (by p53 KD and inhibition of calpain activity) combined with autophagy (by using 3MA) was able to completely prevent necrotic cell death induced by $15 \mu \mathrm{M}$ $\mathrm{Cd}$, and to significantly reduce the number of necrotic cell deaths induced by $30 \mu \mathrm{M} \mathrm{Cd}$.
In conclusion, although necrosis is commonly known as an accidental non-regulated death process, Cd-treated endothelial cells present a highly regulated and complex cell death signalling mechanism which involves a variety of different cell organelles. Apoptotic and autophagy signals induced through $\mathrm{Cd}$ toxicity culminate in necrosis (Fig. 8) and can be prevented by the inhibition of all activated signalling pathways. In summary, our work supports the growing body of evidence of the existence of a highly regulated form of necrosis, as recently reviewed by Vanden Berghe et al. [61].

\section{Study limitations}

The present study is based on several hypotheses, which limit the extensibility of the observed results to the situation in humans. A central limitation is that all observations made are based on an in vitro cell culture model including the chosen $\mathrm{Cd}$ concentrations, which are not necessarily applicable to the situation in humans. Cd-concentrations chosen are based on studies by Abu-Hayyeh et al. [6] who reported on the occurrence of up to $20 \mu \mathrm{M}$ of $\mathrm{Cd}$ in the aortic wall of chronic smokers, and a study by Bergström et al. reporting up to 50 fold increased $\mathrm{Cd}$ concentrations in the vascular intima compared to the blood stream. [62].

Acknowledgments The authors would like to thank Anneliese Steinacher-Nigisch, Birgitta Winter, and Eva Eichmair for their excellent technical assistance and Jackson Shaw Kern for careful proof-reading of the manuscript.

\section{Compliance with ethical standards}

Funding This project was supported by the Austrian National Bank: Anniversary Fund, Project \# 14590 to B.M. and Anniversary Fund, Project \# 14745 to D.B.

Conflict of interest The authors declare no conflict of interest.

Open Access This article is distributed under the terms of the Creative Commons Attribution 4.0 International License (http:// creativecommons.org/licenses/by/4.0/), which permits unrestricted use, distribution, and reproduction in any medium, provided you give appropriate credit to the original author(s) and the source, provide a link to the Creative Commons license, and indicate if changes were made.

\section{References}

1. Satarug S, Moore MR (2004) Adverse health effects of chronic exposure to low-level cadmium in foodstuffs and cigarette smoke. Environ Health Perspect 112(10):1099-1103

2. Jarup L, Akesson A (2009) Current status of cadmium as an environmental health problem. Toxicol Appl Pharmacol 238(3):201-208. doi:10.1016/j.taap.2009.04.020

3. Inaba T, Kobayashi E, Suwazono Y, Uetani M, Oishi M, Nakagawa H, Nogawa K (2005) Estimation of cumulative cadmium 
intake causing Itai-itai disease. Toxicol Lett 159(2):192-201. doi:10.1016/j.toxlet.2005.05.011

4. Satarug S, Baker JR, Urbenjapol S, Haswell-Elkins M, Reilly PE, Williams DJ, Moore MR (2003) A global perspective on cadmium pollution and toxicity in non-occupationally exposed population. Toxicol Lett 137(1-2):65-83

5. Nawrot TS, Staessen JA, Roels HA, Munters E, Cuypers A, Richart T, Ruttens A, Smeets K, Clijsters H, Vangronsveld J (2010) Cadmium exposure in the population: from health risks to strategies of prevention. Biometals Int J Role Metal Ions Biol Biochem Med 23(5):769-782. doi:10.1007/s10534-010-9343-Z

6. Abu-Hayyeh S, Sian M, Jones KG, Manuel A, Powell JT (2001) Cadmium accumulation in aortas of smokers. Arterioscler Thromb Vasc Biol 21(5):863-867

7. Roemmich JN, Lobarinas CL, Joseph PN, Lambiase MJ, Archer Iii FD, Dorn J (2009) Cardiovascular reactivity to psychological stress and carotid intima-media thickness in children. Psychophysiology 46(2):293-299. doi:10.1111/j.1469-8986.2008.00776.x

8. IARC (1997) IARC Monographs on the Evaluation of Carcinogenic Risks to Humans-Beryllium, Cadmium, Mercury, and Exposures in the Glass Manufacturing Industry. Summary of Data Reported and Evaluation. 58. International Agency for cancer Research-World Health Organisation

9. Galluzzi L, Vitale I, Abrams JM, Alnemri ES, Baehrecke EH, Blagosklonny MV, Dawson TM, Dawson VL, El-Deiry WS, Fulda S, Gottlieb E, Green DR, Hengartner MO, Kepp O, Knight RA, Kumar S, Lipton SA, Lu X, Madeo F, Malorni W, Mehlen P, Nunez G, Peter ME, Piacentini M, Rubinsztein DC, Shi Y, Simon HU, Vandenabeele P, White E, Yuan J, Zhivotovsky B, Melino G, Kroemer G (2012) Molecular definitions of cell death subroutines: recommendations of the Nomenclature Committee on Cell Death 2012. Cell Death Differ 19(1):107-120. doi:10.1038/ cdd.2011.96

10. Liu Y, Templeton DM (2008) Initiation of caspase-independent death in mouse mesangial cells by $\mathrm{Cd}^{2+}$ : involvement of $\mathrm{p} 38$ kinase and CaMK-II. J Cell Physiol 217(2):307-318. doi:10. $1002 / j \mathrm{cp} .21499$

11. Lawal AO, Ellis EM (2012) Phospholipase C mediates cadmiumdependent apoptosis in HEK 293 cells. Basic Clin Pharmacol Toxicol 110(6):510-517. doi:10.1111/j.1742-7843.2011.00843.x

12. Xie J, Shaikh ZA (2006) Cadmium-induced apoptosis in rat kidney epithelial cells involves decrease in nuclear factor-kappa B activity. Toxicol Sci Off J Soc Toxicol 91(1):299-308. doi:10. 1093/toxsci/kfj131

13. Lee WK, Torchalski B, Thevenod F (2007) Cadmium-induced ceramide formation triggers calpain-dependent apoptosis in cultured kidney proximal tubule cells. Am J Physiol Cell Physiol 293(3):C839-C847. doi:10.1152/ajpcell.00197.2007

14. Wang SH, Shih YL, Lee CC, Chen WL, Lin CJ, Lin YS, Wu KH, Shih CM (2009) The role of endoplasmic reticulum in cadmiuminduced mesangial cell apoptosis. Chem Biol Interact 181(1):45-51. doi:10.1016/j.cbi.2009.05.004

15. Wang SH, Shih YL, Kuo TC, Ko WC, Shih CM (2009) Cadmium toxicity toward autophagy through ROS-activated GSK-3beta in mesangial cells. Toxicol Sci Off J Soc Toxicol 108(1):124-131. doi:10.1093/toxsci/kfn266

16. Ishido M, Ohtsubo R, Adachi T, Kunimoto M (2002) Attenuation of both apoptotic and necrotic actions of cadmium by Bcl-2. Environ Health Perspect 110(1):37-42

17. Lee WK, Abouhamed M, Thevenod F (2006) Caspase-dependent and -independent pathways for cadmium-induced apoptosis in cultured kidney proximal tubule cells. Am J Physiology Renal Physiol 291(4):F823-F832. doi:10.1152/ajprenal.00276.2005

18. Wang L, Cao J, Chen D, Liu X, Lu H, Liu Z (2009) Role of oxidative stress, apoptosis, and intracellular homeostasis in primary cultures of rat proximal tubular cells exposed to cadmium.
Biol Trace Elem Res 127(1):53-68. doi:10.1007/s12011-0088223-7

19. Gobe G, Crane D (2010) Mitochondria, reactive oxygen species and cadmium toxicity in the kidney. Toxicol Lett 198(1):49-55. doi:10.1016/j.toxlet.2010.04.013

20. Wang SH, Shih YL, Ko WC, Wei YH, Shih CM (2008) Cadmium-induced autophagy and apoptosis are mediated by a calcium signaling pathway. Cell Mol Life Sci CMLS 65(22):3640-3652. doi:10.1007/s00018-008-8383-9

21. Lemarie A, Lagadic-Gossmann D, Morzadec C, Allain N, Fardel O, Vernhet L (2004) Cadmium induces caspase-independent apoptosis in liver Hep3B cells: role for calcium in signaling oxidative stress-related impairment of mitochondria and relocation of endonuclease $\mathrm{G}$ and apoptosis-inducing factor. Free Radic Biol Med 36(12):1517-1531. doi:10.1016/j.freeradbiomed.2004. 03.020

22. Oh SH, Lim SC (2006) A rapid and transient ROS generation by cadmium triggers apoptosis via caspase-dependent pathway in HepG2 cells and this is inhibited through $N$-acetylcysteine-mediated catalase upregulation. Toxicol Appl Pharmacol 212(3):212-223. doi:10.1016/j.taap.2005.07.018

23. Lasfer M, Vadrot N, Aoudjehane L, Conti F, Bringuier AF, Feldmann G, Reyl-Desmars F (2008) Cadmium induces mitochondria-dependent apoptosis of normal human hepatocytes. Cell Biol Toxicol 24(1):55-62. doi:10.1007/s10565-007-9015-0

24. Peters JL, Perlstein TS, Perry MJ, McNeely E, Weuve J (2010) Cadmium exposure in association with history of stroke and heart failure. Environ Res 110(2):199-206. doi:10.1016/j.envres.2009. 12.004

25. Tellez-Plaza M, Navas-Acien A, Menke A, Crainiceanu CM, Pastor-Barriuso R, Guallar E (2012) Cadmium exposure and allcause and cardiovascular mortality in the U.S. general population. Environ Health Perspect 120(7):1017-1022. doi:10.1289/ehp. 1104352

26. Tellez-Plaza M, Guallar E, Howard BV, Umans JG, Francesconi KA, Goessler W, Silbergeld EK, Devereux RB, Navas-Acien A (2013) Cadmium exposure and incident cardiovascular disease. Epidemiology 24(3):421-429. doi:10.1097/EDE. 0b013e31828b0631

27. Everett CJ, Frithsen IL (2008) Association of urinary cadmium and myocardial infarction. Environ Res 106(2):284-286. doi:10. 1016/j.envres.2007.10.009

28. Agarwal S, Zaman T, Tuzcu EM, Kapadia SR (2011) Heavy metals and cardiovascular disease: results from the National Health and Nutrition Examination Survey (NHANES) 1999-2006. Angiology 62(5):422-429. doi:10.1177/0003319710395562

29. Messner B, Knoflach M, Seubert A, Ritsch A, Pfaller K, Henderson B, Shen YH, Zeller I, Willeit J, Laufer G, Wick G, Kiechl S, Bernhard D (2009) Cadmium is a novel and independent risk factor for early atherosclerosis mechanisms and in vivo relevance. Arterioscler Thromb Vasc Biol 29(9):1392-1398. doi:10. 1161/ATVBAHA.109.190082

30. Jung YS, Jeong EM, Park EK, Kim YM, Sohn S, Lee SH, Baik EJ, Moon CH (2008) Cadmium induces apoptotic cell death through p38 MAPK in brain microvessel endothelial cells. Eur J Pharmacol 578(1):11-18. doi:10.1016/j.ejphar.2007.08.049

31. Kim J, Lim W, Ko Y, Kwon H, Kim S, Kim O, Park G, Choi H, Kim O (2012) The effects of cadmium on VEGF-mediated angiogenesis in HUVECs. J Appl Toxicol JAT 32(5):342-349. doi:10.1002/jat.1677

32. Wolf MB, Baynes JW (2007) Cadmium and mercury cause an oxidative stress-induced endothelial dysfunction. Biometals Int $\mathbf{J}$ Role Metal Ions Biol Biochem Med 20(1):73-81. doi:10.1007/ s10534-006-9016-0

33. Seok SM, Park DH, Kim YC, Moon CH, Jung YS, Baik EJ, Moon CK, Lee SH (2006) COX-2 is associated with cadmium-induced 
ICAM-1 expression in cerebrovascular endothelial cells. Toxicol Lett 165(3):212-220. doi:10.1016/j.toxlet.2006.04.007

34. Jeong EM, Moon CH, Kim CS, Lee SH, Baik EJ, Moon CK, Jung YS (2004) Cadmium stimulates the expression of ICAM-1 via NF-kappaB activation in cerebrovascular endothelial cells. Biochem Biophys Res Commun 320(3):887-892. doi:10.1016/j.bbrc. 2004.05.218

35. Park SL, Kim YM, Ahn JH, Lee SH, Baik EJ, Moon CH, Jung YS (2009) Cadmium stimulates the expression of vascular cell adhesion molecule-1 (VCAM-1) via p38 mitogen-activated protein kinase (MAPK) and JNK activation in cerebrovascular endothelial cells. J Pharmacol Sci 110(3):405-409

36. Majumder S, Muley A, Kolluru GK, Saurabh S, Tamilarasan KP, Chandrasekhar S, Reddy HB, Purohit S, Chatterjee S (2008) Cadmium reduces nitric oxide production by impairing phosphorylation of endothelial nitric oxide synthase. Biochemistry and cell biology. Biochimie et biologie cellulaire 86(1):1-10. doi: $10.1139 / 007-146$

37. Majumder S, Gupta R, Reddy H, Sinha S, Muley A, Kolluru GK, Chatterjee S (2009) Cadmium attenuates bradykinin-driven nitric oxide production by interplaying with the localization pattern of endothelial nitric oxide synthase. Biochemistry and cell biology. Biochimie et biologie cellulaire 87(4):605-620. doi:10.1139/o09018

38. Nagarajan S, Rajendran S, Saran U, Priya MK, Swaminathan A, Siamwala JH, Sinha S, Veeriah V, Sonar P, Jadhav V, Jaffar Ali BM, Chatterjee S (2013) Nitric oxide protects endothelium from cadmium mediated leakiness. Cell Biol Int 37(5):495-506. doi: $10.1002 /$ cbin. 10070

39. Liu F, Jan KY (2000) DNA damage in arsenite- and cadmiumtreated bovine aortic endothelial cells. Free Radic Biol Med 28(1):55-63

40. Kolluru GK, Tamilarasan KP, Geetha Priya S, Durgha NP, Chatterjee S (2006) Cadmium induced endothelial dysfunction: consequence of defective migratory pattern of endothelial cells in association with poor nitric oxide availability under cadmium challenge. Cell Biol Int 30(5):427-438. doi:10.1016/j.cellbi.2006. 02.002

41. Woods JM, Leone M, Klosowska K, Lamar PC, Shaknovsky TJ, Prozialeck WC (2008) Direct antiangiogenic actions of cadmium on human vascular endothelial cells. Toxicol In Vitro Int J Publ Assoc BIBRA 22(3):643-651. doi:10.1016/j.tiv.2007.12.009

42. Dong Z, Wang L, Xu J, Li Y, Zhang Y, Zhang S, Miao J (2009) Promotion of autophagy and inhibition of apoptosis by low concentrations of cadmium in vascular endothelial cells. Toxicol In Vitro An Int J Publ In Assoc BIBRA 23(1):105-110. doi:10. 1016/j.tiv.2008.11.003

43. Messner B, Ploner C, Laufer G, Bernhard D (2012) Cadmium activates a programmed, lysosomal membrane permeabilizationdependent necrosis pathway. Toxicol Lett 212(3):268-275. doi:10.1016/j.toxlet.2012.05.026

44. Bernhard D, Pfister G, Huck CW, Kind M, Salvenmoser W, Bonn GK, Wick G (2003) Disruption of vascular endothelial homeostasis by tobacco smoke: impact on atherosclerosis. FASEB J 17(15):2302-2304. doi:10.1096/fj.03-0312fje

45. Flora SJ, Pachauri V (2010) Chelation in metal intoxication. International journal of environmental research and public health 7(7):2745-2788. doi:10.3390/ijerph7072745

46. Fotakis G, Cemeli E, Anderson D, Timbrell JA (2005) Cadmium chloride-induced DNA and lysosomal damage in a hepatoma cell line. Toxicol In Vitro Int J Publ Assoc BIBRA 19(4):481-489. doi:10.1016/j.tiv.2005.02.001

47. Fotakis G, Timbrell JA (2006) In vitro cytotoxicity assays: comparison of LDH, neutral red, MTT and protein assay in hepatoma cell lines following exposure to cadmium chloride. Toxicol Lett 160(2):171-177. doi:10.1016/j.toxlet.2005.07.001

48. Cao F, Zhou T, Simpson D, Zhou Y, Boyer J, Chen B, Jin T, Cordeiro-Stone M, Kaufmann W (2007) p53-Dependent but ATM-independent inhibition of DNA synthesis and G2 arrest in cadmium-treated human fibroblasts. Toxicol Appl Pharmacol 218(2):174-185. doi:10.1016/j.taap.2006.10.031

49. Person RJ, Tokar EJ, Xu Y, Orihuela R, Ngalame NN, Waalkes MP (2013) Chronic cadmium exposure in vitro induces cancer cell characteristics in human lung cells. Toxicol Appl Pharmacol 273(2):281-288. doi:10.1016/j.taap.2013.06.013

50. Zhou Z, Wang C, Liu H, Huang Q, Wang M, Lei Y (2013) Cadmium induced cell apoptosis, DNA damage, decreased DNA repair capacity, and genomic instability during malignant transformation of human bronchial epithelial cells. Int J Med Sci 10(11):1485-1496. doi:10.7150/ijms.6308

51. Orrenius S, Zhivotovsky B, Nicotera P (2003) Regulation of cell death: the calcium-apoptosis link. Nat Rev Mol Cell Biol 4(7):552-565. doi:10.1038/nrm1150

52. Zhivotovsky B, Orrenius S (2011) Calcium and cell death mechanisms: a perspective from the cell death community. Cell Calcium 50(3):211-221. doi:10.1016/j.ceca.2011.03.003

53. White C, Li C, Yang J, Petrenko NB, Madesh M, Thompson CB, Foskett JK (2005) The endoplasmic reticulum gateway to apoptosis by $\mathrm{Bcl}-\mathrm{X}(\mathrm{L})$ modulation of the InsP3R. Nat Cell Biol 7(10):1021-1028. doi:10.1038/ncb1302

54. Khorchid A, Ikura M (2002) How calpain is activated by calcium. Nat Struct Biol 9(4):239-241. doi:10.1038/nsb0402-239

55. Smith MA, Schnellmann RG (2012) Calpains, mitochondria, and apoptosis. Cardiovasc Res 96(1):32-37. doi:10.1093/cvr/cvs163

56. Rizzuto R, Pinton P, Carrington W, Fay FS, Fogarty KE, Lifshitz LM, Tuft RA, Pozzan T (1998) Close contacts with the endoplasmic reticulum as determinants of mitochondrial $\mathrm{Ca}^{2+}$ responses. Science 280(5370):1763-1766

57. Malhotra JD, Kaufman RJ (2011) ER stress and its functional link to mitochondria: role in cell survival and death. Cold Spring Harb Perspect Biol 3(9):a004424. doi:10.1101/cshperspect.a004424

58. Turk B, Turk V (2009) Lysosomes as "suicide bags" in cell death: myth or reality? J Biol Chem 284(33):21783-21787. doi:10.1074/jbc.R109.023820

59. Yuan XM, Li W, Dalen H, Lotem J, Kama R, Sachs L, Brunk UT (2002) Lysosomal destabilization in p53-induced apoptosis. Proc Natl Acad Sci USA 99(9):6286-6291. doi:10.1073/pnas. 092135599

60. Rodriguez GEV, Torriglia A (2013) Calpain 1 induce lysosomal permeabilization by cleavage of lysosomal associated membrane protein 2. Biochim Biophys Acta 1833(10):2244-2253. doi:10. 1016/j.bbamcr.2013.05.019

61. Vanden Berghe T, Linkermann A, Jouan-Lanhouet S, Walczak H, Vandenabeele P (2014) Regulated necrosis: the expanding network of non-apoptotic cell death pathways. Nat Rev Mol Cell Biol 15(2):135-147. doi:10.1038/nrm3737

62. Bergstrom G, Fagerberg B, Sallsten G, Lundh T, Barregard L (2015) Is cadmium exposure associated with the burden, vulnerability and rupture of human atherosclerotic plaques? PLoS One 10(3):e0121240. doi:10.1371/journal.pone.0121240 